\title{
Mobilized permafrost carbon is concentrated in particulate matter and ebullition methane in Northern Quebec thaw lakes
}

\author{
Regina Gonzalez Moguel ${ }^{1}$ Peter Douglas ${ }^{2}$
} AdRIAN M. BASS ${ }^{3}$ MARTIN PILOTE ${ }^{4}$ MARK H GARNETT ${ }^{5}$

${ }^{1}$ McGill University, regina.gonzalezmoguel@mail.mcgill.ca

${ }^{2}$ McGill University, peter.douglas@mcgill.ca

${ }^{3}$ University of Glasgow, adrian.bass@glasgow.ac.uk

${ }^{4}$ Environment and Climate Change Canada, martin.pilote@canada.ca

${ }^{5}$ NERC Radiocarbon Lab, mark.garnett@glasgow.ac.uk

Permafrost thaw can potentially mobilize millennial aged carbon across the Arctic and Subarctic, with significant implications for carbon cycle feedbacks to climate change. Widespread permafrost degradation has been recorded in Northern Quebec (Canada) over the past 30 years, but it remains unclear to what extent old carbon is being mobilized, transported, and mineralized to methane $\left(\mathrm{CH}_{4}\right)$ and carbon dioxide $\left(\mathrm{CO}_{2}\right)$ in aquatic systems. To answer this, we measured the radiocarbon age of dissolved and ebullition $\mathrm{CH}_{4}$, ebullition $\mathrm{CO}_{2}$, dissolved inorganic carbon (DIC), dissolved organic carbon (DOC), particulate organic carbon (POC), and surficial sediment carbon from one river and three thaw lakes associated with peatlands, and two rivers and two thaw lakes associated with mineral soils.

In peatland lakes, carbon older than permafrost formation in the area $(>300$ yrs BP) is a major component of sedimentary carbon $(\sim 3630$ yrs BP), POC ( 1360 yrs BP), and ebullition $\mathrm{CH}_{4}(\sim 1395$ yrs BP $)$, but comprises a smaller component of DOC ( $\sim 880 \mathrm{yrs}$ BP) and dissolved $\mathrm{CH}_{4}$ and $\mathrm{CO}_{2}$ (modern to $700 \mathrm{yrs} \mathrm{BP}$ ). Similarly, the peatland river transports relatively old POC ( $\sim 2830$ yrs BP $)$ and DIC $(\sim 1030$ yrs BP), but younger DOC ( $\sim 335$ yrs BP). In the mineral lakes, surficial sediments $(\sim 1000 \mathrm{yrs} B P)$ and POC $(\sim 630 \mathrm{yrs}$ BP) contained carbon dating to the period of local permafrost formation $\left(\sim 1050-300\right.$ yrs BP), but DOC, DIC, and all $\mathrm{CH}_{4}$ pools were primarily modern in age. Similarly, DOC and DIC in the non-peatland rivers was modern, but $\mathrm{POC}$ was older ( 670 yrs BP).

These results indicate old deep peat and permafrost organic carbon has been mobilized into Northern Quebec aquatic systems. The results also suggest that the geological setting strongly influences the fate of old carbon in these systems, with old carbon in peatland lakes and rivers forming a larger component of mobilized carbon and greenhouse gas emissions than in mineral soil regions. 